\title{
PENGARUH PROFITABILITAS DAN RASIO PASAR TERHADAP HARGA SAHAM PADA PT BANK MANDIRI TBK PERIODE 2010 - 2020
}

\author{
$1^{*}$ Dewi Nari Ratih Permada, ${ }^{2}$ Ajeng Nur Aprianti \\ Universitas Pamulang, Tangerang Selatan, Banten, Indonesia \\ 1*dewi.permada00821@unpam.ac.id, 2nurapriantiajeng@gmail.com
}

\begin{abstract}
Abstrak
Penelitian ini bertujuan untuk mengetahui pengaruh Return on Asset (ROA) dan Earning Per Share (EPS) terhadap Harga Saham pada PT Bank Mandiri Tbk periode 2010-2020. Metode penelitian yang digunakan adalah metode kuantitatif dengan pendekatan deskriptif. Alat analisis yang digunakan adalah regresi linier berganda dan koefisien determinasi. Berdasarkan hasil penelitian besarnya pengaruh Return On Asset (ROA) dan Earning Per Share (EPS) secara keseluruhan terhadap harga saham sebesar 67,1\%. Sedangkan sedangkan sisanya sebesar $32,8 \%$ adalah pengaruh faktor-faktor lain. Uji hipotesis secara simultan Return On Asset dan Earning Per Share berpengaruh signifikan terhadap Harga Saham. Sedangkan secara parsial Return On Asset dan Earning Per Share berpengaruh signifikan terhadap Harga Saham.
\end{abstract}

Kata Kunci: Return on Asset, Earning Per Share, dan Harga Saham

Abstract

This study aims to determine the effect of Return on Assets (ROA) and Earning Per Share (EPS) on stock prices at PT Bank Mandiri Tbk for the 2010-2020 period. The research method used is a quantitative method with a descriptive approach. The analytical tool used is multiple linear regression and coefficient of determination. Based on the results of the study the magnitude of the effect of Return On Assets (ROA) and Earning Per Share (EPS) on the stock price as a whole is $67.1 \%$. Meanwhile, while the remaining $32.8 \%$ is the influence of other factors. Simultaneous hypothesis testing Return On Assets and Earning Per Share have a significant effect on stock prices. While partially Return On Assets and Earnings Per Share has a significant effect on stock prices.

Keywords: Return on Asset, Earning Per Share, and Stock Price

\section{PENDAHULUAN}

Perkembangan sektor perbankan di Indonesia menarik untuk dicermati. Kekuatan sistem perbankan merupakan persyaratan penting untuk memastikan stabilitas dan pertumbuhan ekonomi. Bank adalah bagian utama dari sektor keuangan yang bertahan di tengah kondisi perekonomian di Indonesia. Perbankan mempunyai peran yang sangat vital dalam pencapaian tujuan nasional yang berkaitan dalam peningkatan dan pemerataan taraf hidup masyarakat.

Masyarakat dan investor akan menilai peran dan kinerja bank melalui harga saham yang beredar. Saham merupakan satuan nilai atau pembukuan dalam berbagai instrumen finansial yang mengacu pada bagian kepemilikan sebuah perusahaan. Dalam teori ekonomi, harga saham harus mencerminkan ekspektasi bagaimana kinerja perusahaan dimasa yang akan datang dan keuntungan perusahaan secara umum dapat mencerminkan tingkat aktivitas ekonomi.

Harga saham merupakan nilai suatu perusahaan yang mencerminkan kekayaan suatu perusahaan tersebut. Perubahan harga saham ditentukan dari tingkat permintaan dan penawaran, semakin banyak investor yang ingin membeli saham maka harga akan semakin naik, sebaliknya semakin banyak investor yang menjual atau melepaskan saham, harga akan bergerak turun. Salah satu faktor yang dipertimbangkan investor dalam memilih perusahaan untuk diinvestasikan adalah kinerja dan kesehatan suatu perusahaan (Firman dan Desi; 2019).

Grafik dibawah ini menjelaskan perkembangan Harga Saham (Closing Price) PT Bank Mandiri Tbk tahun 2010 - 2020 (Harga saham dalam Satuan Rupiah). 


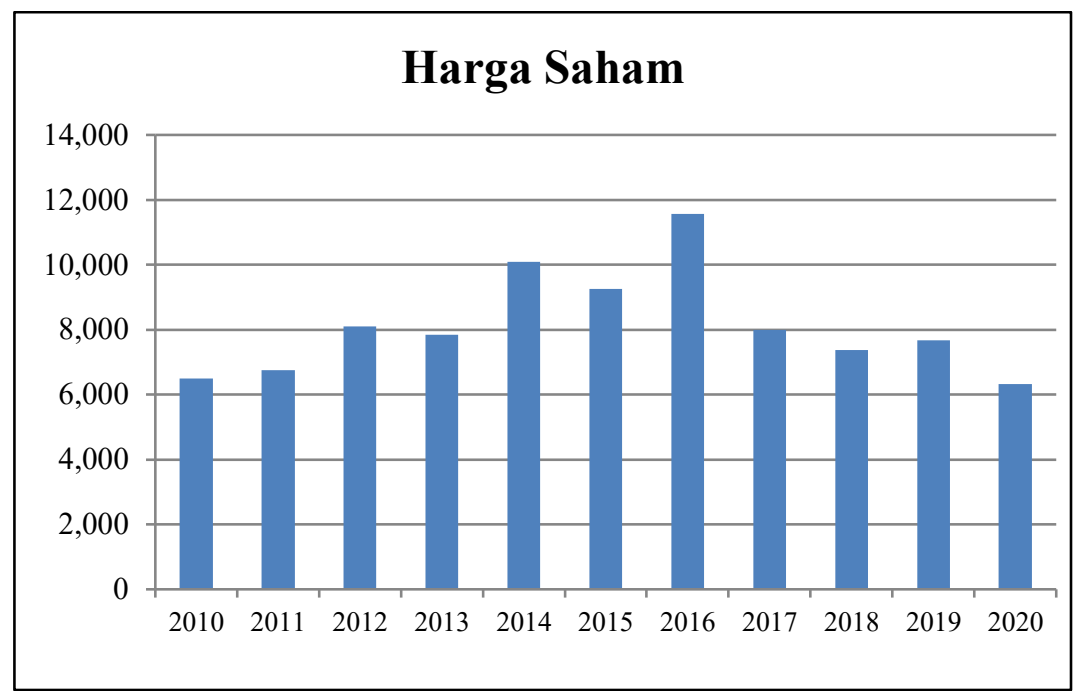

Sumber : Laporan Keuangan PT Bank Mandiri Tbk

Gambar 1. Fluktuasi Harga Saham

Terlihat bahwa harga saham PT Mandiri Tbk berfluktuasi namun dalam periode 2016 sampai dengan 2020 cenderung menurun. Indikasi ini tidak baik bagi PT Bank Mandiri Tbk sehingga perlu diteliti mengapa dalam lima tahun terakhir harga saham cenderung menurun.

Selain harga saham yang menjadi parameter kinerja dan keberhasilan perusahaan, profitabilitas juga merupakan faktor yang penting untuk dibahas. Dalam penelitian ini profitabiltas diproksikan dengan Return on Asset (ROA). ROA menunjukkan kemampuan perusahaan dalam menghasilkan laba atas total aktiva yang dimilikinya. Return On Assets dipakai untuk mengevaluasi apakah manajemen telah mendapat imbalan yang memadai dari aset yang dikuasainya. Rasio ini digunakan oleh manajemen untuk mengevaluasi unitunit bisnis di dalam suatu perusahaan multinasional (Alipudin dan Resi : 2016).

Berikut ini gambar indikator ROA dalam 11 tahun terakhir PT Bank Mandiri Tbk. (Dalam satuan Milyar Rupiah).

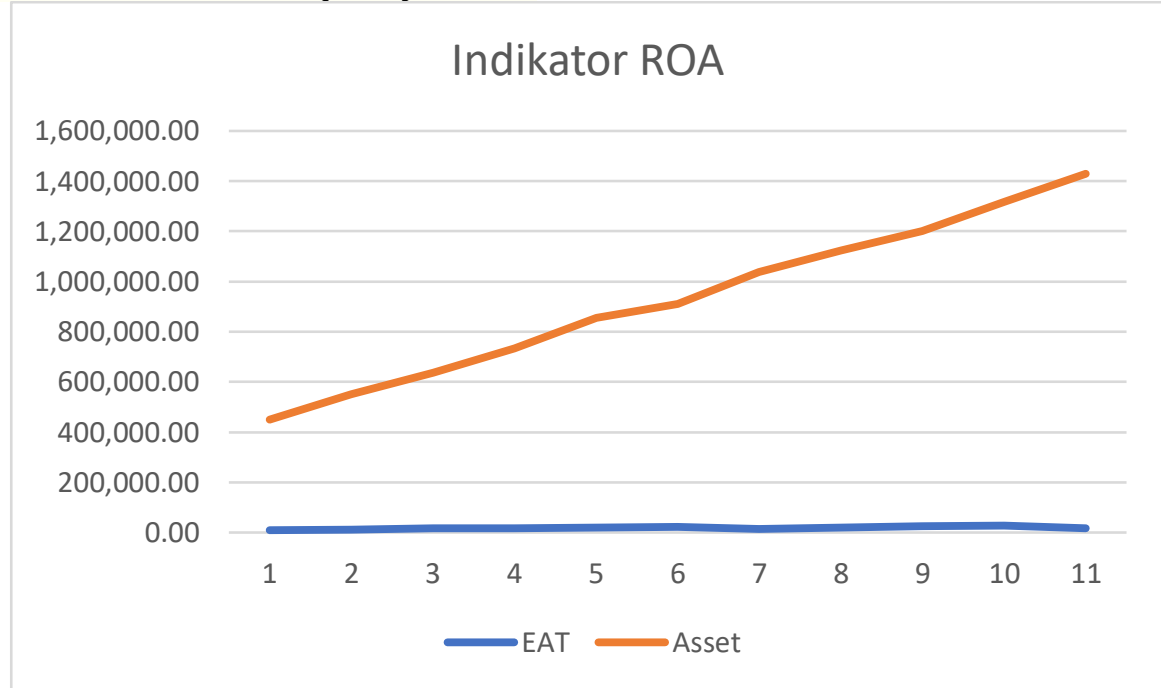

Sumber : Laporan Keuangan PT Bank Mandiri Tbk

Gambar 2. Fluktuasi Indikator ROA

Dari gambar di atas terlihat bahwa penambahan total aktiva (asset) tidak diimbangi dengan penambahan laba bersih setelah pajak (EAT). Hal ini menandakan bahwa PT Bank Mandiri Tbk belum dapat mengolah total aset yang dimiliki untuk menghasilkan keuntungan/ laba. Hal ini perlu diteliti lebih lanjut mengapa masalah ini bisa terjadi sehingga diharapkan hasil penelitian ini dapat memberikan saran atau rekomendasi buat manajemen untuk meningkatkan ROA di tahun mendatang. 
Hal yang tak penting selain harga saham dan ROA dalam menilai keberhasilan suatu entitas selain keuntungan atau laba adalah rasio pasar. Rasio pasar dalam penelitian ini diproksikan dengan earning per share (EPS). EPS merupakan indikator keberhasilan perusahaan dalam mengelola bisnisnya di mata masyarakat khususnya investor. EPS merupakan laba bersih setelah pajak dibanding dengan jumlah saham yang beredar. Jika EPS nya tinggi hal ini akan menarik pihak masyarakat atau investor untuk menanamkan modalnya atau akan membeli sahamnya. Semakin tinggi EPS maka akan menaikkan harga saham dan meningkatkan nilai perusahaan (Khan, T. R., et al., 2014).

Berikut fluktuasi dari indicator EPS PT Bank Mandiri Tbk dalam kurun waktu 11 tahun terakhir (Dalam satuan Milyar Rupiah dan ribuan lembar saham).

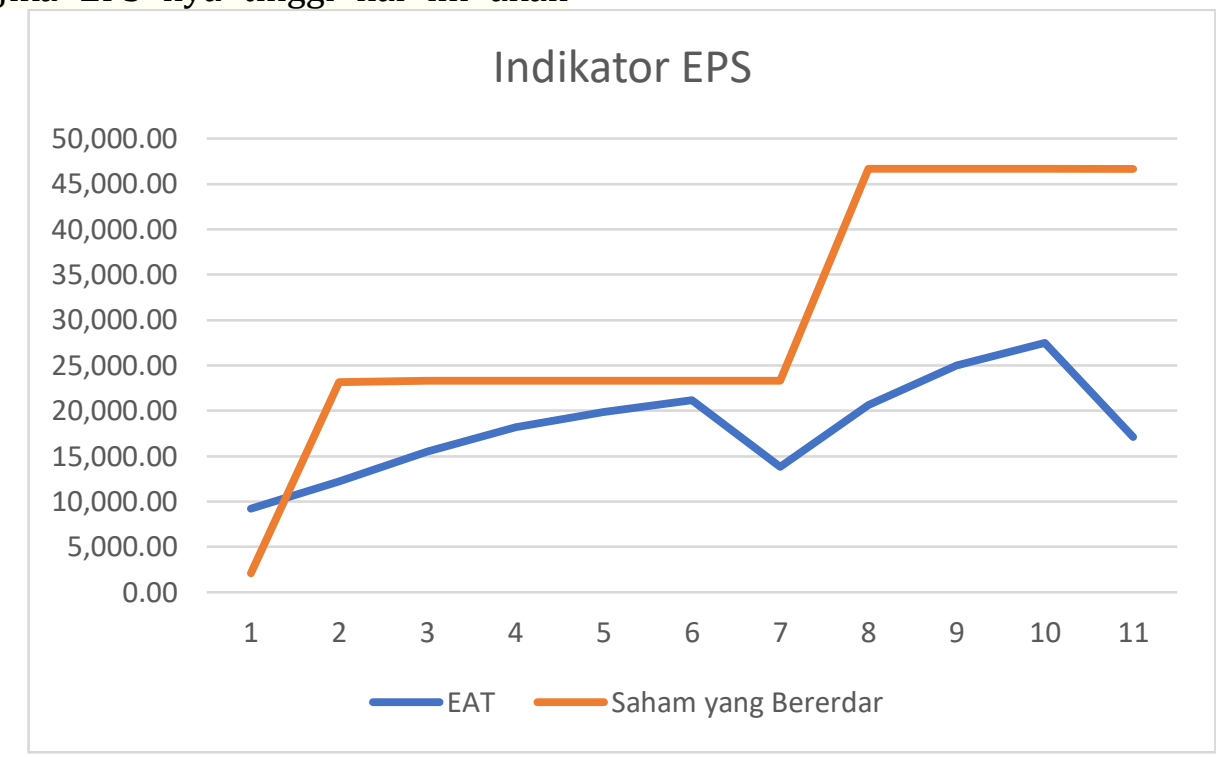

Sumber : Laporan Keuangan PT Bank Mandiri Tbk

Gambar 3. Fluktuasi Indikator EPS

Dari gambar diatas terlihat bahwa perolehan laba setelah pajak megalami fluktuasi yang cukup tinggi dimana sejak tahun 2019 sampai 2021 mengalami penurunan sedangkan jumlah lembar saham yang beredar mengalami fluktuasi yang cenderung meningkat. Ini berakibat nilai EPS berfluktuasi namun cenderung menurun karena pertumbuhan laba setelah pajak tidak sebesar pertumbuhan jumlah saham yang beredar. Kondisi ini sangat menarik untuk diteliti, mengapa nilai EPS cenderung fluktuasi yang mengalami penurunan dalam 11 tahun terakhir ini.

Semakin tinggi ROA dan semakin tinggi nilai EPS maka akan menaikkan tingkat kepercayaan masayarakat atau investor terhadap keberhasilan atau kinerja perusahaan tersebut. Masyarakat dan investor akan semakin percaya untuk mengivestasikan dananya kepada perusahaan yang menunjukkan kinerja yang baik. Kinerja yang baik ini dapat diindikasikan dengan harga saham yang semakin naik atau semakin tinggi. Penelitian yang dilakukan oleh Dewi dan Parlia (2017) EPS mempunyai dampak baik bagi kinerja keuangan perusahaan, karena setiap investor yang melakukan investasi di pasar modal mengharapkan keuntungan dari dana yang ditanamkan. Jika nilai Earning Per Share sesuai dengan harapan investor, maka perubahan harga saham akan mengalami peningkatan seiring dengan minat investor untuk membeli saham tersebut Anggi dkk (2020).

Beberapa hasil penelitian terdahulu mengai tema serupa antara lain, penelitian Rizal dan Susanti (2014) menhasilkan secara simultan terdapat pengaruh Return on Assets (ROA) dan Earning Per Share (EPS) terhadap harga saham. Sedangkan hasil penelitian menurut Ahmad dan Anava (2020) bahwa Return on Assets (ROA) dan Earning Per Share (EPS) secara simultan berpengaruh tidak signifikan terhadap Harga Saham.

Dari fenomena di atas serta perbedaan hasil dari penelitian terdahulu maka 
penelitian ini semakin menarik untuk dilakukan. Oleh karena itu peneliti mengambil tema penelitian yang berjudul Pengaruh Profitabilitas dan Rasio Pasar Terhadap Harga Saham pada PT Bank Mandiri Tbk Periode 2010 - 2020.

\section{TINJAUAN PUSTAKA}

\section{Harga Saham}

Menurut Siti Suhariana (2015) Harga Saham adalah harga suatu saham pada pasar yang sedang berlangsung di Bursa Efek. Harga Saham dapat dipengaruhi oleh situasi pasar antara lain harga saham dipasar perdana ditentukan oleh penjamin emisi dan perusahaan yang akan go public (emiten), berdasarkan analisis fundamental perusahaan. Harga saham merupakan harga jual beli yang sedang berlaku di pasar efek yang ditentukan oleh kekuatan pasar dalam arti tergantungan pada kekuatan permintaan (penawaran) dan penawaran (permintaan jual). Harga pasar saham juga menunjukkan nilai dari perusahaan itu sendiri.

\section{Return on Asset (ROA)}

Menurut Alipudin dan Resi (2016) Return on Asset (ROA) memberikan indikasi seberapa efisien suatu perusahaan dalam menggunakan total aset mereka untuk menghasilkan laba. Semakin besar rasio ini maka perusahaan lebih efisien dalam penggunaan aset. Sangat penting untuk mengambil ratarata total aset karena aset cenderung sering berubah setiap periodenya.

ROA berfungsi untuk mengukur efektivitas perusahaan dalam menghasilkan laba dengan memanfaatkan aktiva yang dimilikinya. Semakin besar ROA yang dimiliki suatu perusahaan maka semakin efisien pengguna aktiva sehingga akan memperbesar laba. Laba yang besar akan menarik investor karena perusahaan memiliki tingkat pengembalian yang semakin tinggi.

\section{Earning Per Share (EPS)}

Menurut Dewi dan Parlia (2017:73) Earning Per Share (EPS) merupakan rasio yang mengukur seberapa besar dividen per lembar saham yang akan dibagikan kepada investor setelah dikurangi dengan dividen. Jika nilai Earning Per Share sesuai dengan harapan investor, maka perubahan harga saham akan mengalami peningkatan seiring dengan minat investor untuk membeli saham tersebut. Apabila EPS perusahaan tinggi, akan semakin banyak investor yang ingin membeli saham tersebut sehingga menyebabkan harga saham akan tinggi. Makin tinggi nilai EPS maka semakin besar laba yang akan disediakan untuk pemegang saham.

\section{METODE}

Penelitian dilakukan dengan pendekatan kuantitatif yang bersifat objektif mencakup pengumpulan dan analisis data kuantitatif serta menggunakan metode pengujian statsistik. Metode kuantitatif merupakan metode ilmiah karena telah memenuhi kaidah-kaidah ilmiah yang konkrit/empiris, obyektif, terukur, rasional, dan sistematis. Dalam penyusunan proposal skripsi ini, penelitian dilakukan dengan mengambil data di halaman http://bankmandiri.co.id yang diterbitkan oleh PT Bank Mandiri dan di akses melalui situs. Data yang diambil adalah laporan keuangan tahun 2010-2020 PT Bank Mandiri Tbk.

Metode analisis data yang digunakan dalam melakukan penelitian ini yaitu menggunakan Analisis Uji Deskriptif, Uji Asumsi Klasik (Uji Normalitas, Uji Non Multikolinearitas, Uji Non Heterokedastisitas, Uji Non Autokorelasi,), Analisis Regresi Linear Berganda, Koefisien Korelasi, Koefisien Determinasi, Uji Hipotesisis Secara Parsial (Uji t), Uji Hipotesis Secara Simultan (Uji f).

\section{HASIL DAN PEMBAHASAN}

\section{Analisis Rasio Keuangan}

\section{a. Return on Asset (ROA)}

Return on Asset merupakan rasio untuk menunjukkan seberapa jauh asset perusahaan digunakan secara efektif untuk menghasilkan laba. ROA didapatkan dari membagi laba sebelum bunga dan pajak dengan total asset. Rasio ini merupakan rasio keuangan yang digunakan untuk mengukur kinerja perusahaan, khususnya menyangkut profitabilitas perusahaan. Semakin tinggi ROA menunjukkan 
perusahaan semakin efektif menghasilkan laba bersih atas asset yang dimilikinya. Berikut merupakan hasil perhitungan ROA yang telah diolah dan dapat dilihat pada tabel dan grafik berikut :

Tabel 1. Hasil Perhitungan Return on Asset (ROA) Pada PT Bank Mandiri Persero Tbk Periode 2010-2020

\begin{tabular}{|c|c|c|c|c|}
\hline \multirow{2}{*}{ No. } & \multirow{2}{*}{ Tahun } & $\begin{array}{c}\text { Laba Bersih } \\
\text { Setelah Pajak }\end{array}$ & Total Asset & ROA \\
\cline { 3 - 5 } & & \multicolumn{2}{|c|}{ (Dalam Jutaan Rp) } & (\%) \\
\hline 1 & 2010 & 9.218 .298 & 449.774 .551 & $2,05 \%$ \\
\hline 2 & 2011 & 12.246 .044 & 551.891 .704 & $2,22 \%$ \\
\hline 3 & 2012 & 15.504 .067 & 635.618 .708 & $2,44 \%$ \\
\hline 4 & 2013 & 18.203 .753 & 733.099 .762 & $2,48 \%$ \\
\hline 5 & 2014 & 19.871 .873 & 855.039 .673 & $2,32 \%$ \\
\hline 6 & 2015 & 21.152 .398 & 910.063 .409 & $2,32 \%$ \\
\hline 7 & 2016 & 13.806 .565 & 1.038 .706 .009 & $1,33 \%$ \\
\hline 8 & 2017 & 20.639 .683 & 1.124 .700 .847 & $1,84 \%$ \\
\hline 9 & 2018 & 25.015 .021 & 1.202 .252 .094 & $2,08 \%$ \\
\hline 10 & 2019 & 27.482 .133 & 1.318 .246 .335 & $2,08 \%$ \\
\hline 11 & 2020 & 17.119 .253 & 1.429 .334 .484 & $1,20 \%$ \\
\hline
\end{tabular}

Sumber: Sumber diolah

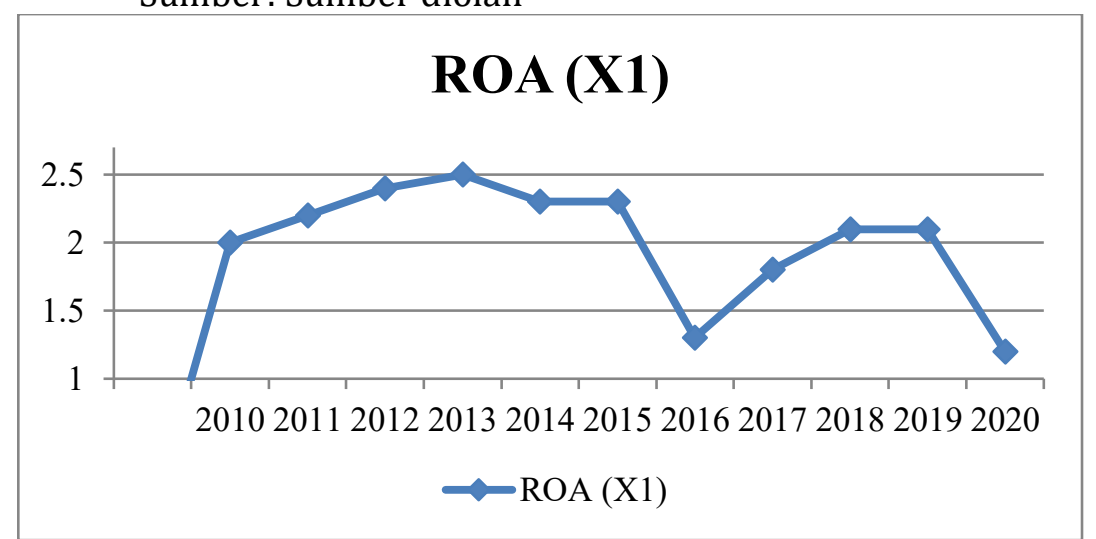

Gambar 4. Total Return on Asset (ROA)

Berdasarkan tabel dan grafik di atas nilai dapat bahwa nilai ROA mengalami penurunan dan peningkatan yang relatif kecil. Pada tahun 2015 - 2016 penurunan terjadi cukup besar padahal ini menunjukkan bahwa perusahaan harus lebih efektif dalam memanfaatkan aset yang dimilikinya untuk menghasilkan laba.

\section{b. Earning per Share (EPS)}

Earning per Share merupakan rasio yang menunjukkan bagian laba yang diterima investor untuk setiap lembar saham. EPS didapatkan dari membagi laba bersih dengan jumlah saham beredar. Informasi EPS merupakan informasi yang dianggap paling mendasar dan berguna karena dapat menggambarkan prospek perusahaan dimasa mendatang. Berikut merupakan hasil perhitungan ROA yang telah diolah dan dapat dilihat pada tabel dan grafik berikut :

Tabel 2. Hasil Perhitungan Earning per Share (EPS) Pada PT Bank Mandiri Persero Tbk Periode 2010-2020 (Dalam Jutaan Rupiah)

\begin{tabular}{|c|c|c|c|c|}
\hline \multirow{2}{*}{ No. } & \multirow{2}{*}{ Tahun } & $\begin{array}{c}\text { Laba Bersih } \\
\text { Setelah Pajak }\end{array}$ & $\begin{array}{c}\text { Saham yang } \\
\text { Bererdar }\end{array}$ & EPS \\
\cline { 3 - 5 } & & (Rp) & (Rp) & $(\%)$ \\
\hline 1 & 2010 & 9.218 .298 & 20.993 .040 & $43,91 \%$ \\
\hline 2 & 2011 & 12.246 .044 & 23.134 .862 & $52,93 \%$ \\
\hline 3 & 2012 & 15.504 .067 & 23.333 .333 & $66,45 \%$ \\
\hline 4 & 2013 & 18.203 .753 & 23.333 .333 & $78,02 \%$ \\
\hline 5 & 2014 & 19.871 .873 & 23.333 .333 & $85,17 \%$ \\
\hline
\end{tabular}




\begin{tabular}{|c|c|c|c|c|}
6 & 2015 & 21.152 .398 & 23.333 .333 & $90,65 \%$ \\
\hline 7 & 2016 & 13.806 .565 & 23.333 .333 & $59,17 \%$ \\
\hline 8 & 2017 & 20.639 .683 & 46.666 .666 & $44,23 \%$ \\
\hline 9 & 2018 & 25.015 .021 & 46.666 .666 & $53,60 \%$ \\
\hline 10 & 2019 & 27.482 .133 & 46.666 .666 & $58,89 \%$ \\
\hline 11 & 2020 & 17.119 .253 & 46.631 .266 & $36,71 \%$ \\
\hline
\end{tabular}

Sumber: Hasil olah data

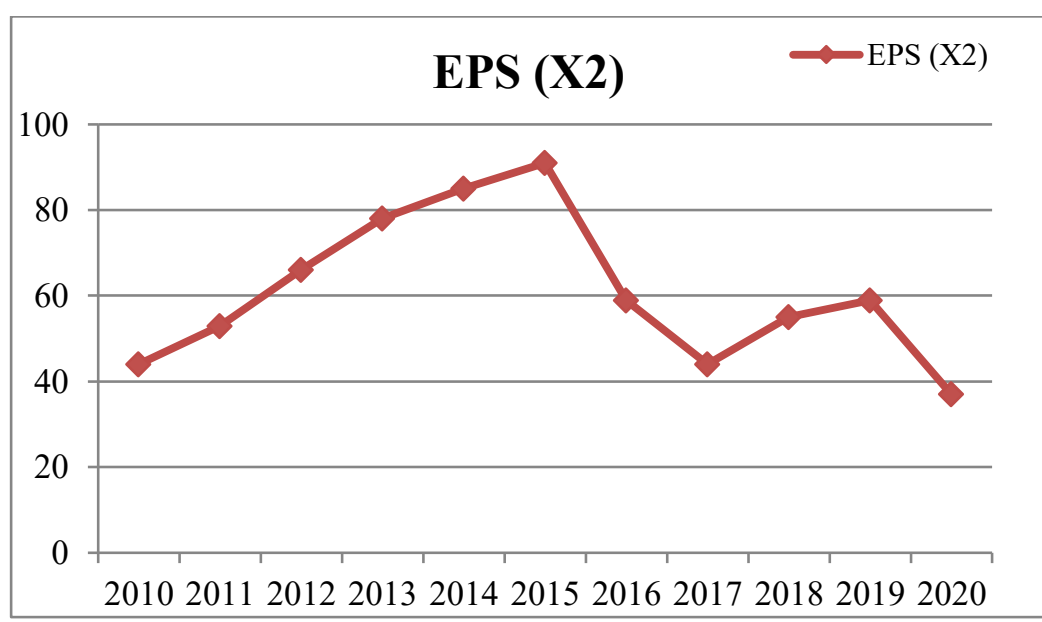

Gambar 4. Total Earning per Share (EPS)

Berdasarkan tabel dan grafik di atas nilai EPS periode 2010-2013 mengalami peningkatan yang signifikan, hal tersebut menunjukkan semakin tinggi nilai EPS tentu saja menyebabkan semakin besar laba dan kemungkinan peningkatan jumlah deviden yang diterima pemegang saham.

\section{Analisis Deskriptif Data}

Deskriptif data digunakan untuk mendeskripsikan dan menggambarkan suatu data yang terdapat dalam penelitian dengan melihat nilai rata-rata (mean), nilai máximum, nlai mínimum, dan estándar deviasi dari setiap variabel. Hasil analisis deskriptif data adalah sebagai berikut:

Tabel 3. Hasil Analisis Deskriptif Data

Descriptive Statistics

\begin{tabular}{cc|c|c|c|c} 
& $\mathrm{N}$ & Minimum & Maximum & Mean & Std. Deviation \\
\hline ROA & 11 & 12.00 & 25.00 & 20.1818 & 4.26188 \\
\hline EPS & 11 & 37.00 & 91.00 & 60.9091 & 17.50688 \\
\hline Harga Saham & 11 & 6.33 & 11.58 & 8.1364 & 1.60298 \\
\hline Valid N (listwise) & 11 & & & & \\
\hline
\end{tabular}

Sumber: Hasil olah data SPSS

Berdasarkan tabel deskriptif di atas, maka dapat dijelaskan sebagai berikut:

a. Pada tampilan tabel output spss di atas pada variabel X1 (ROA) menunjukkan jumlah sampel (N) ada 11, nilai minimum yaitu 12,00 , nilai maksimum adalah 25,00, nilai rata-rata yaitu 20,1818 dan nilai standar deviasi sebesar 4,26188 .

b. Pada variabel X2 (EPS) menunjukkan jumlah sampel (N) adalah 11, nilai minimum adalah 37,00, nilai maksimum adalah 91,00, nilai rata-rata adalah 60,9091 dan nilai standar deviasi sebesar 17,50688. c. Pada variabel Y (Harga Saham) menunjukkan jumlah sampel $(\mathrm{N})$ ada 11 , nilai minimum adalah 6,33 , nilai maksimum adalah 11,58 , nilai rata-rata adalah 8,1364, dan nilai standar deviasi sebesar 1,60298.

\section{Analisis Regresi Linear Berganda}

Analisis regresi linear berganda bertujuan untuk mencari pengaruh dari dua atau lebih variabel independen (X) terhadap variabel dependen (Y). hasil perhitungan regresi linear berganda dalam penelitian ini adalah sebagai berikut: 
Tabel 4. Hasil Uji Analisis Regresi Linear Berganda

\section{Coefficients ${ }^{\mathrm{a}}$}

\begin{tabular}{|c|c|c|c|c|c|c|}
\hline \multirow[b]{3}{*}{ Mode } & & \multirow{2}{*}{\multicolumn{2}{|c|}{$\begin{array}{l}\text { Unstandardized } \\
\text { Coefficients }\end{array}$}} & \multirow{3}{*}{$\begin{array}{c}\text { Standardized } \\
\text { Coefficients } \\
\text { Beta } \\
\end{array}$} & \multirow[b]{3}{*}{$\mathrm{T}$} & \multirow[b]{3}{*}{ Sig. } \\
\hline & & & & & & \\
\hline & & B & Std. Error & & & \\
\hline \multirow[t]{3}{*}{1} & (Constant) & 8.047 & 1.580 & & 5.093 & .001 \\
\hline & ROA & -.291 & .100 & -.773 & -2.909 & .020 \\
\hline & EPS & .098 & .024 & 1.068 & 4.020 & .004 \\
\hline
\end{tabular}

Sumber: Hasil olah data SPSS

Berdasarkan tabel Coefficients di atas maka dapat dijelaskan tentang persamaan regresi berganda dalam penelitian ini. Adapun rumus persamaan regresi berganda dalam penelitian ini adalah:

$$
\begin{aligned}
& Y=\alpha+\beta 1 X 1+\beta 2 X 2+\varepsilon \\
& Y=8,047-0,291 X 1+0,098 X 2
\end{aligned}
$$

Uji Korelasi bertujuan untuk mengetahui tingkat keeratan hubungan antar variabel yang dinyatakan dengan Koefisien Korelasi (r), jenis hubungan antar variabel $\mathrm{X}$ dan $\mathrm{Y}$ yang dapat bersifat positif atau negatif. Hasil uji koefisien korelasi dalam penelitian ini adalah sebagai berikut:

\section{Koefisien Korelasi}

Tabel 5. Hasil Uji Koefisien Korelasi

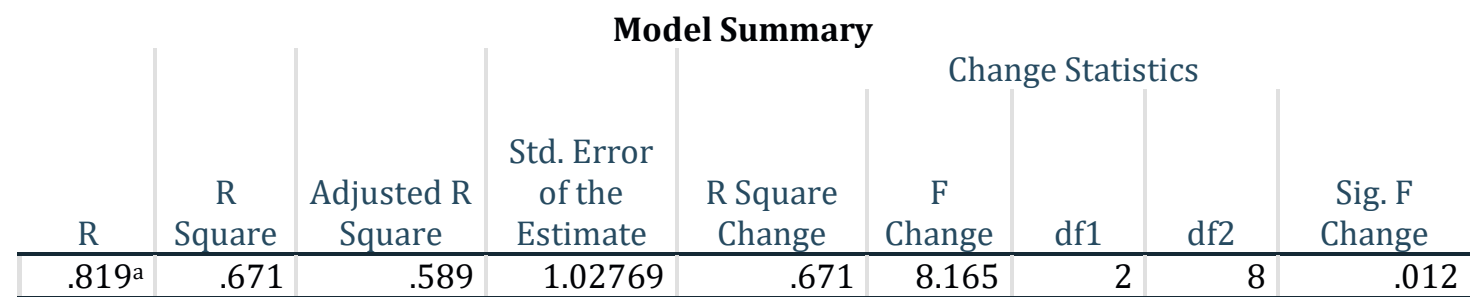

a. Predictors: (Constant), EPS, ROA

Berdasarkan tabel di atas diketahui nilai sig. F Change sebesar 0,012 dan nilai probabilitas sebesar 0,05 , maka nilai sig. $\mathrm{F}$ Change lebih kecil dari probabilitas $(0,012$ $<0,05$ ) artinya terdapat korelasi ROA dan EPS terhadap Harga Saham. Sedangkan derajat hubungan yang dimiliki ROA dan EPS terhadap Harga saham mempunyai nilai 0,819 yang berarti mempunyai hubungan korelasi sempurna.

Tabel 6. Hasil Uji Koefisien Determinasi (R Square)

\begin{tabular}{ll|l|c|c} 
& \multicolumn{2}{|c}{ Model Summary } \\
Model & R & R Square & $\begin{array}{c}\text { Adjusted R } \\
\text { Square }\end{array}$ & $\begin{array}{c}\text { Std. Error of } \\
\text { the Estimate }\end{array}$ \\
\hline 1 & $.819^{\mathrm{a}}$ & .671 & .589 & 1.02769 \\
\hline
\end{tabular}

a. Predictors: (Constant), EPS, ROA

b. Dependent Variable: Harga Saham

Sumber: Hasil olah data SPSS

Berdasarkan tabel di atas diketahui nilai R Square sebesar 0,671 maka hal ini dapat diartikan bahwa pengaruh variabel independen secara simultan terhadap variabel dependen sebesar 67,1\%. Sedangkan sisanya $(100 \%-67,1 \%=$ $32,8 \%$ ) dipengaruhi oleh variabel lain di luar persamaan regresi ini atau variabel

\section{Koefisien Determinasi (R Square)}

Koefisien determinasi (R Square) bertujuan untuk mengukur seberapa besar presentase pengaruh variabel independen terhadap variabel dependen dalam satuan persen pada sebuah model regresi. Hasil uji koefisien determinasi dalam penelitian ini adalah sebagai berikut: yang tidak diteliti.

\section{Uji Hipotesis}

\section{a. Uji T}

Dalam melakukan Uji T parsial pengambilan keputusan bisa dengan melihat nilai Sig, maka dari itu dalam penelitian ini menggunakan nilai 
signifikan $5 \%$ atau 0,05 dengan kriteria jika P value (Sig) > dari Ho diterima artinya tidak ada pengaruh signifikan variabel independen terhadap variabel dependen. Sementara jika P value (Sig) $\leq$ Ho ditolak yang dapat diartikan ada

$$
\begin{array}{lcc}
\text { pengaruh } & \text { signifikan } & \text { variabel } \\
\text { independen } & \text { terhadap } & \text { variabel } \\
\text { dependen. } & &
\end{array}
$$

Hasil dari Uji T dalam penelitian ini adalah sebagai berikut:

Tabel 7. Hasil Uji T

Coefficients $^{\mathrm{a}}$

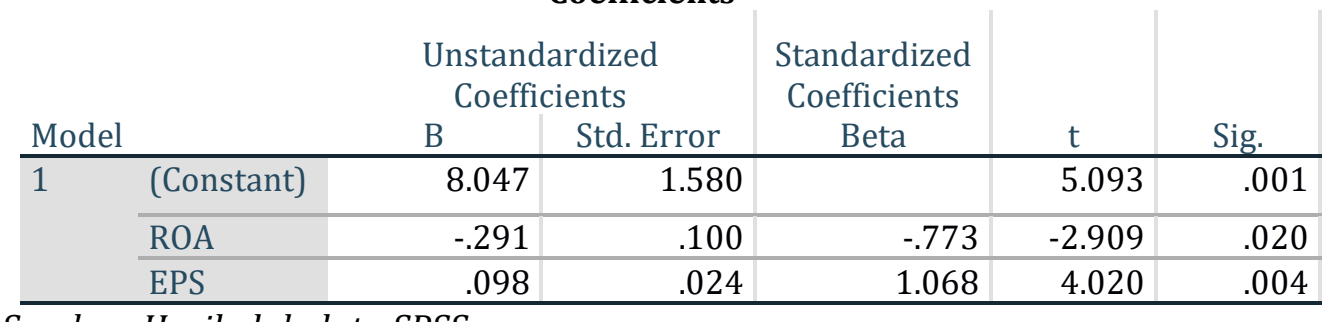

Sumber: Hasil olah data SPSS

Berdasarkan tabel di atas maka pengaruh setiap variabel independen terhadap variabel dependen adalah:

1) Pengujian ROA (X1) terhadap Harga Saham (Y)

Ho1 : $\beta 1=0$ artinya ROA tidak berpengaruh positif terhadap Harga Saham.

Ha1 : $\beta 1>0$ artinya ROA berpengaruh positif signifikan terhadap Harga Saham

Diketahui nilai Sig variabel R0A adalah sebesar 0,020 dan nilai probabilitas 0,05 maka untuk pengaruh ROA (X1) terhadap Harga Saham (Y) sebesar 0,020 $<0,05$ dan nilai $t_{\text {hitung }}|-2,909|>t_{\text {tabel }} 1,860$ sehingga dapat disimpulkan bahwa Ho1 ditolak dan Ha1 diterima. Artinya terdapat pengaruh ROA (X1) terhadap Harga Saham (Y).

2) Pengujian EPS (X2) terhadap Harga Saham (Y)

Ho2 : $\beta 2=0$ artinya EPS tidak berpengaruh positif terhadap Harga Saham.

Ha2 : $\beta 2>0$ artinya EPS berpengaruh positif signifikan terhadap Harga Saham.

Dalam hipotesis kedua dalam penelitian ini adalah EPS (X2) diketahui nilai signifikansi (Sig) variabel EPS (X2) adalah sebesar 0,04 dan nilai probabilitas 0,05 maka untuk pengaruh EPS (X2) terhadap Harga Saham (Y) adalah sebesar $0,04<0,05$ dan nilai $t_{\text {hitung }} 4,020>t_{\text {tabel }} 1,860$ sehingga dapat disimpulkan bahwa Ho1 ditolak dan $\mathrm{Ha} 2$ diterima. Artinya terdapat pengaruh EPS (X2) terhadap Harga Saham (Y).

\section{b. Uji F}

Uji $\mathrm{F}$ digunakan untuk mengetahui pengaruh variabel independen terhadap variabel dependen pada penelitian secara simultan. Pada Uji F memakai nilai signifikan $5 \%$ atau 0,05 dengan kriteria jika P value (Sig) $>\alpha$ maka Ho diterima yang berarti tidak ada pengaruh signifikan variabel independen terhadap variabel dependen. sedangkan jika $\mathrm{P}$ value $(\mathrm{Sig}) \leq \alpha$ maka Ho ditolak dimana artinya ada pengaruh signifikan variabel independen terhadap variabel dependen.

Maka hasil Uji $\mathrm{F}$ dalam penelitian ini

\begin{tabular}{|c|c|c|c|c|c|c|}
\hline \multicolumn{7}{|c|}{ ANOVA $^{\mathrm{a}}$} \\
\hline & Model & Sum of Squares & Df & $\begin{array}{c}\text { Mean } \\
\text { Square }\end{array}$ & $\mathrm{F}$ & Sig. \\
\hline \multirow{3}{*}{1} & Regression & 17.246 & 2 & 8.623 & 8.165 & $.012^{\mathrm{b}}$ \\
\hline & Residual & 8.449 & 8 & 1.056 & & \\
\hline & Total & 25.695 & 10 & & & \\
\hline
\end{tabular}
adalah sebagai berikut:

Tabel 8. Hasil Uji F

a. Dependent Variable: Harga Saham

b. Predictors: (Constant), EPS, ROA 
Ho3 : ROA dan EPS secara simultan tidak berpengaruh terhadap Harga Saham

Ha3 : ROA dan EPS secara simultan berpengaruh terhadap Harga Saham

Berdasarkan tabel di atas diketahui nilai signifikan untuk pengaruh ROA (X1) dan EPS (X2) secara simultan terhadap Harga Saham (Y) sebesar $0,012<0,05$ dan nilai $F_{\text {hitung }}$
8,165 > $\mathrm{F}_{\text {tabel }} 4,26$ sehingga dapat disimpulkan bahwa terdapat pengaruh ROA (X1) dan EPS (X2) secara simultan terhadap Harga Saham (Y).

Berdasarkan pengujian hipotesis Pengaruh Return on Assets (ROA) dan Earning Per Share (EPS) terhadap Harga Saham dengan menggunakan aplikasi SPSS versi 25, maka didapat hasil sebagai berikut:

Tabel 9. Hasil Pengujian Hipotesis

\begin{tabular}{|c|c|c|}
\hline & Pernyataan & Hasil \\
\hline $\mathrm{Ha}_{1}$ & Return on Assets (ROA) tidak berpengaruh terhadap Harga Saham & Hipotesis Diterima \\
\hline $\mathrm{Ha}_{2}$ & Earning per Sahre (EPS) berpengaruh terhadap Harga Saham & Hipotesis Diterima \\
\hline & Return on Assets (ROA) dan Earning per Sahre (EPS) & Hipotesis \\
$\mathrm{Ha}_{3}$ & secara simultan berpengaruh terhadap Harga Saham & Diterima \\
\hline
\end{tabular}

Sumber : Data diolah oleh penulis

\section{PENUTUP}

\section{KESIMPULAN}

a. Variabel ROA pada penelitian ini berpengaruh signifikan terhadap Harga Saham.

b. Variabel EPS pada penelitian ini berpengaruh signifikan terhadap Harga Saham.

c. Semua variabel bebas dalam penelitian ini yaitu ROA dan EPS berpengaruh signifikan terhadap Harga Saham.

\section{SARAN}

a. Berdasarkan hasil penelitian ini variabel ROA dan EPS secara bersamasama berpengaruh terhadap variabel harga saham sehingga dapat dikatakan bahwa harga saham pada PT Bank Mandiri Tbk dipengaruhi oleh perubahan ROA dan EPS perusahaan itu sendiri. Sebaiknya investor atau pelaku pasar apabila akan membeli saham di sektor perbankan juga melihat bagaimana keadaan fundamental perusahaan tersebut seperti price to book value (PBV), debt to Equity (DER), price to earning ratio (PER), dan non-performing loan (NPL).

b. Peneliti selanjutnya diharapkan bisa menambah variabel bebasnya seperti PER, NPL, NPM, DER, dan lain-lain untuk melihat lebih jauh pengaruhnya terhadap harga saham pada perusahaan perbankan.

c. Bagi masyarakat yang mau membeli saham hendaknya meneliti terdahulu
EPS dan ROA suatu perusahaan sebelum memutuskan untuk berinvestasi dan juga memperhatikan variabel fundamental perusahaan lainnya yang dapat mempengaruhi harga saham perusahaan.

\section{DAFTAR PUSTAKA}

Alipudin, A \& Oktaviani, R. (2016). Pengaruh EPS, ROE, ROA Dan DER Terhadap Harga Saham Pada Perusahaan Sub Sektor Semen Yang Terdaftar Di BEI. JIAFE (Jurnal Ilmiah Akuntansi Fakultas Ekonomi) Volume 2 No. 1 Edisi 1. 1-22.

Anderson, Melissa. (2015). "Pengaruh Corporate Social Responsibility Terhadap Respon Investor pada Perusahaan Non Kapitalisasi Besar (Non-Big Capitalization) di Indonesia." Business Accounting Review 03 (1): 316-326.

Azhari, D., F \& Rahayu, S. M. (2016), "Pengaruh ROE, DER, TATO dan PER Terhadap Harga Saham Perusahaan Properti Dan Real Estate Yang Go Publik Di Bursa Efek Indonesia". 5.

Buchari, S. S. (2015). Pengaruh ROE, ROA, dan EPS Terhadap Harga Saham PT UNILEVER INDONESIA Tbk (PERIODE 2007-2014). Makassar : Universitas Islam Negeri Alauddin.

Darmaji, T. \& Fakhruddin, H.M. (2018). Pasar Modal di Indonesia, Pendekatan Tanya Jawab. Jakarta: Salemba Empat.

Febianto, A. (2015). "Pengaruh Return On Asset, Current Ratio, Debt To Equity 
Ratio, Dividen, Laba Bersih, Dan Dividend Payout Ratio Terhadap Harga Saham Pada Perusahaan Yang Terdaftar Di Jakarta Islamic Index Periode 2009-2014." Jurnal Ekonomi Syari'ah 02 (1): 34-46.

Haque, M. G., et al. (2021). Micro Financial Sharia Non-bank Strategic Analysis: a Study at BMT Beringharjo, Yogyakarta. Budapest International Research and Critics Institute (BIRCI-Journal): Humanities and Social Sciences, 4(2), 1677-1686.

Hendrawan, R, H. (2020). Pengaruh Return On Assets, Debt To Equity Ratio Dan, Earning Per Share Terhadap Harga Saham (Pada Perusahaan Perbankan Yang Terdaftar Di Bursa Efek Indonesia Tahun 2016-2019). 1-12.

Indah, D. R., \& Parlia (2017). Pengaruh Earning Per Share Terhadap Harga Saham Pada PT. Bank Mega Tbk. JURNAL PENELITIAN EKONOMI AKUNTANSI (JENSI): VOL. 1, NO. 1, JUNI 2017: 72-81.

Khan, T. R., Islam, M., Choudhury, T. T., \& Adnan, A. M. (2014). How earning per share (EPS) affects on share price and firm value.

Kumaidi, R, K \& Asandimitra, N. (2017). Pengaruh ROA, ROE, DER, DPR, Dan LDR Terhadap Harga Saham Sektor Perbankan Bei Periode 2011 - 2016 (Dengan Penggolongan Kapitalisasi Kecil Dan Kapitalisasi Besar ). Jurnal Ilmu Manajemen Volume 5 Nomor 3. 113.

Muttaqin, M. R., \& Susanti. (2014). Pengaruh ROA, ROE, dan EPS terhadap Perubahan Harga Saham Industri Perbankan. Jurnal Ilmu Manajemen : Volume 1 Nomor 4, Juli 2013 : 1255 - 1264.

Nainggolan, A. (2019). Pengaruh Eps, Roe, Npm, Der, Per Terhadap Harga Saham Pada Perusahaan Perbankan Yang Terdaftar Dibursa Efek Indonesia Periode 2014-2017. Jurnal Manajemen Volume 5 Nomor 1. 61-70.

Nufusa, S, H., \& Sahronib, N. (2020). Pengaruh Return On Asset, Retur On Equity Dan Earning Per Share Terhadap Harga Saham (Survey Pada PT. Bank Mandiri (Persero) Tbk). BanKu : Jurnal Perbankan dan Keuangan : Volume 1
Nomor 2, Agustus 2020 : 85 - 93.

Nurfadilah, M. (2015). "Analisis Pengaruh Earnings Per Share, Debt ToEquity Ratio, dan Return On Equity Terhadap Harga Saham PT. Unilever, Tbk." Jurnal Manajemen dan Akuntansi 12 (1): 4550.

Pangaribuan, A. A., \& Suryono, B. (2019). Pengaruh ROA, ROE, Dan EPS Terhadap Harga Saham Perusahaan Transportasi di BEI. Jurnal Ilmu dan Riset Akuntansi : Volume 8 Nomor 5, Mei 2019: 1 -15.

Permada, D. N. R,. (2019). Pengaruh Quick Ratio, DER, Dan Working Capital Turnover Terhadap Pertumbuhan Laba PY Wijaya Karya Tbk Tahun 2007 2017. JURNAL SEKURITAS: Vol.2, No.3, Mei 2019: 1-19.Permada, D. N. R,. (2018). Analisis Pengaruh Penerapan Good Corporate Governance Dan Rencana Strategis Terhadap Peningkatan Kinerja Unit Internal Audit \& Control PT. Gmf Aero Asia. JURNAL SEKURITAS: Vol.1, No. 3, Maret 2018: 46-69.

Permada, D. N. R., \& Susriat, U. (2018). Pengaruh Debt To Equity Ratio Dan Total Assets Turnover Terhadap Return On Equity Pada PT. Arwana Citramulia, Tbk, Tahun 2008-2017. Prosising Seminar Nasional Program Studi Manajemen, Fakultas Ekonomi, Universitas Pamulang: 194-206.

Permatasari, N. D., Nurlaela, S., \& Titisari, K. H. (2019). Return On Assets, Return On Equity, Earning Per Share Terhadap Harga Saham Perusahaan Sektor Jasa Di Bursa Efek Indonesia. Jurnal Edunomika : Vol. 03 No. 01, Februari $2019: 90-96$.

Pujiati, H., et al. (2021). Effect of ISO 9001: 2015 Quality Management Implementation in Education on School Performance. Journal of Contemporary Issues in Business and Government, 27(1), 1848-1855.

Purwoko, G. D, \& Permada, D. N. R. (2020). Analisa Kinerja Keuangan Pt Blue Bird Periode Tahun 2015 S/D 2019. Jurnal Proaksi: Vol. 7 No. 2 Juli - Desember 2020: 82-89.

Ramdhani, R. (2014). Pengaruh Return On Assets Dan Debt To Equity Ratio Terhadap Harga Saham Pada Institusi 
Finansial Di Bursa Efek Indonesia. Journal The WINNERS, Vol. 14 No. 1, Maret 2013. 29-41.

Sari, A. N., Suharti, T., \& Immas, N. (2020). Pengaruh Return On Asset Return On Equity Dan Earning Per Share Terhadap Harga Saham Perusahaan. Ejournal uikabogor : Volume 3 No 1, Februari $2020: 59-64$.

Setiawan, F,. \& Desi, I. R. (2019). PENGARUH RETURN ON ASSET (ROA), RETURN ON EQUITY (ROE) DAN EARNING PER SHARE (EPS) TERHADAP HARGA SAHAM SYARIAH Studi Kasus PT. Aneka Tambang Persero Tbk Tahun 2013-2017. JURNAL LISAN AL-HAL: Volume 13, No. 2, Desember 2019: 258280.

Setyorini. (2016). "Pengaruh Return On Asset (ROA), Return On Equity (ROE),dan Earning Per Share (EPS) Terhadap Harga Saham Perusahaan Real Estate di Bursa Efek Indonesia (Studi Kasus Pada 20 Perusahaan 20 Perusahaan Periode 2011-2015)." Journal Of Management 02 (2).

Suhartono, A., et al. (2019). Pengaruh Earning Per Share Dan Return On Asset Terhadap Harga Saham Pada PT. Bank
Negara Indonesia Tbk Periode 20092018. Jurnal Manajemen, Bisnis dan Organisasi (JUMBO), 3(3), 182-194.

Sujatmiko. W. (2019). Pengaruh ROE, ROA, dan EPS Terhadap Harga Saham pada Perusahaan Perbankan yang Terdaftar di Bursa Efek Indonesia. Yogyakarta : Universitas Islam Indonesia.

Umar, A. U. A. A., \& Savitri, A, S, N. (2020). Analisis Pengaruh ROA, ROE, EPS Terhadap Harga Saham. Jurnal Analisa Akuntansi dan Perpajakan : Volome 4 Nomor 1, Maret $2020: 30-36$

Watung, R. S \& Ilat, V,. (2016). Pengaruh Return On Asset (Roa), Net Profit Margin (Npm), Dan Earning Per Share (Eps) Terhadap Harga Saham Pada Perusahaan Perbankan Di Bursa Efek Indonesia Periode 2011-2015. Jurnal EMBA : Volume 4 No.2, Juni 2016 : 518529.

Youriza, Y., Gama, A. W. S., \& Astiti, N. P. Y. (2019). Pengaruh Debt To Equity Ratio, Return On Equity, Dan Return On Assets Terhadap Harga Saham Pada Perusahaan Farmasi Yang Terdaftar Di Bursa Efek Indonesia (Bei) Tahun 2014-2018. 79-87. 